\title{
Attitude and Perceived Barriers towards Research among Undergraduate Medical Students of Bangladesh
}

Jannatul Ferdoush $^{1 *}$, Fatema Johora ${ }^{2}$, IkramUllah Khan ${ }^{3}$, Sharif Mohammad Towfiq Hossain ${ }^{4}$, Halima Sadia $^{5}$, Fatiha Tasmin Jeenia ${ }^{6}$, Sameera Shafique Chowdhury ${ }^{7}$, Nagina Sultana ${ }^{8}$, Shagorika Sharmeen ${ }^{9}$ Authors Detail;

1.Associate Professor

Department of Pharmacology

BGC Trust Medical College, Chattogram.

Jannat_fkh@yahoo.com

8801856189977

Orcid id:0000-0002-6920-7267

\section{Corresponding author}

2. Associate Professor

Department of Pharmacology \& Therapeutics

Army Medical College Bogura, Bogura

Fatemajohora.0801@gmail.com

3. Professor, Department of Pharmacology

Army Medical College, Chattogram

iullah.khan67@gmail.com

4.Medical Officer, Department of Endocrine and Metabolism

Chattogram Maa-O-Shishu Hospital Medical College

towfiqhossain0@gmail.com

5. Assistant Professor

Department of Physiology

Army Medical College Chattogram

hspapri@gmail.com

6.Assistant Professor

Department of Pharmacology \& Therapeutics

Chattogram International Medical College \& Hospital, Chattogram

fatihatasmin@gmail.com

7. Project Research Physician, Icddr,b

sameerashafique@gmail.com

8. Assistant Professor

Department of Dermatology \& Venereology 
medRxiv preprint doi: https://doi.org/10.1101/2021.04.30.21256373; this version posted May 2, 2021. The copyright holder for this preprint (which was not certified by peer review) is the author/funder, who has granted medRxiv a license to display the preprint in perpetuity.

It is made available under a CC-BY-NC-ND 4.0 International license .

Marine City Medical College \& Hospital, Chattogram

9. Assistant Professor

Department of Surgery

Marine City Medical College \& Hospital, Chattogram

\begin{abstract}
:
Background: Undergraduate research opportunities teach students not only how to conduct research, but they too learn problem-solving aptitudes. Participating in research also increases students' interest is being involved and making special contributions to the academic field. Therefore, the aim of our study was intended to assess the attitude and perceived barriers toward research among the medical undergraduates of Bangladesh.

Methods: A cross-sectional questionnaire survey was conducted among third, fourth, and fifth year students across medical colleges in Bangladesh, during the month of July, 2020 to December, 2020. A Google-linked questionnaire was disseminated to the students via different social platform and the responses were received through Google drive.

Result: The questionnaire survey received responses from 1279 students, with $94 \%$ claiming to be familiar with the scientific method. $82.7 \%$ of students mentioned they could design and execute a research project as well as can write scientific articles. More than half of the respondents (66.4\%) expressed an interest in participating in research. Almost all respondents (96.7\%) agreed that research is beneficial as it aid critical thinking and policy implementation. $79.8 \%$ of respondents opined that education on research methodology should be required in the medical curriculum. Majority of the respondents reported that lack of time and priorities to do research work because of compact academic tasks $(89.1 \%)$, insufficient guidance $(86.6 \%)$, lack of familiarities with research methodology $(87.5 \%)$ and statistical analysis $(85.2 \%)$ are the barriers of research.

Conclusion: Our findings indicated that Bangladeshi medical students have a positive attitude toward research and that research methodology should be taught in undergraduate medical education. In order to increase participation in research, the challenges identified by students should be addressed.
\end{abstract}

Keywards: Undergraduate Medical Research, Attitude, Barrier, Medical Education. 
medRxiv preprint doi: https://doi.org/10.1101/2021.04.30.21256373; this version posted May 2, 2021. The copyright holder for this preprint (which was not certified by peer review) is the author/funder, who has granted medRxiv a license to display the preprint in perpetuity. It is made available under a CC-BY-NC-ND 4.0 International license .

Introduction:

There is a constant influx of new knowledge in today's world where new ideas are emerging, and old ideas are being reshaped or replaced. Physician need to learn how to verify authentic information in this era of information epidemics. In order to advance the medical profession, research is essential in this age of evidence-based medicine to offer the best possible treatment to the patient [1]. There is a growing concern about research in both developing and developed countries, as medical research has the potential to improve healthcare [2]. Access to research experience at undergraduate level could be crucial for future physicians as they will be acquainted with the process of generating scientific evidence as well as the challenges and health issues that people, societies, and health systems face requires scientific study from the early days of their career, and it might be reflected throughout their life. Students engaged in research develop specific research skills, self-confidence, self-directed learning, critical thinking, and communication skills $[3,4]$. On the other hand, incorporation and inclusion of medical students in basic research could be a way to address the shortage of medical scientists. [5]

Over the last three decades, efforts to encourage undergraduate research have increased. In 1978, the United States established the Council on Undergraduate Research (CUR) [6]. According to "outcomes for Graduates 2018," the General Medical Council (GMC) found research to be a top priority in medical education [7]. Student-selected components (SSCs) that are used in the curriculum of many UK medical schools with the aim of increasing student exposure to research [8]. The Medical Research Volunteer Program (MRVP) was established in Lebanon 2014 to assist undergraduate students participating in medical research [9]. Here in Bangladesh, research activities are still in its infancy [10]. While research methodology are included in undergraduate programs in many countries,[11] but not included in medical curricula of Bangladesh and many other developing countries [12]. Bangladesh International Medical Students' Science Congress (BIMSSCON) has promoted scientific education among medical students of Bangladesh since its inception in 2015 , by providing a forum for them to exchange ideas, information, and improves networking [13]. IFMSA Bangladesh (The International Federation of Medical Students Associations) is a medical student-run organization in Bangladesh. Since 2015, it has been involved in activities such as SCOREsearch, a three-month training program on the fundamentals of research methodology designed to give students a hands-on approach and help them to develop their capacity [14].

Though students have a positive attitude toward science, they need a supportive and positive atmosphere in order to enhance their research knowledge, develop skills, and resolve the barriers of conducting scientific research [15]. Several studies have shown that the presence of research obstacles contributes to differences in research theory and conduct [16]. Lack of proper knowledge and skills in scientific method 
medRxiv preprint doi: https://doi.org/10.1101/2021.04.30.21256373; this version posted May 2, 2021. The copyright holder for this preprint (which was not certified by peer review) is the author/funder, who has granted medRxiv a license to display the preprint in perpetuity. It is made available under a CC-BY-NC-ND 4.0 International license .

and statistics and lack of interest in research, lack of time as set extra burden, lack of training, lack of reward, lack of motivation, and lack of supervision all are identified as obstacles in scientific research $[17,18]$. In most cases, students are reluctant to participate in research due to lack of scientific training programs and inadequate supervision [18]. A positive research experience requires the role of a supervisor and a good relationship with the supervisor [19]. The huge curriculum and lack of time in medical education is the main reason why students are less involved in research. As a result, they do not have the skills to write protocols in post graduation.

It is possible to improve students' awareness and attitude toward research by making research projects mandatory in undergraduate curriculum as part of research methodology [18, 20]. It is important to understand undergraduate students' attitudes towards research and the obstacles they face in conducting research. Current study was conducted with the aim to assess the attitude and perceived barriers toward research among the medical undergraduates of Bangladesh in order to intervene and take the appropriate measures to overcome the obstacles by recognizing them in upcoming days.

Materials and Methods:

Study design and population:

The cross sectional questionnaire survey was conducted among the $3^{\text {rd }}, 4^{\text {th }}$ and $5^{\text {th }}$ year medical student across the medical colleges of Bangladesh during the month of July, 2020 to December 2020. Ethical approval was taken from institutional review board (IRB) of BGC trust medical college, Chattogram. The student was informed about their participation is voluntary and to maintain the confidentiality the response was anonymous.

Study procedure: A Google-linked questionnaire was developed based on literature search and pilot test were carried out to 30 medical students of $3^{\text {rd }}, 4^{\text {th }}$ and $5^{\text {th }}$ year to check its clarity and reliability. However, the responses were not included in this survey.

The questionnaire was disseminated to the student via different facebook Page and Groups of medical students of Bangladesh, whats app, messenger, and other social platform. Few students volunteer were selected from different medical colleges to distribute the questionnaire and properly address the study. The responses were received through Google drive. The automated Google form received only one response from one email address to ovoid duplicate or multiple responses from a single respondent. 
medRxiv preprint doi: https://doi.org/10.1101/2021.04.30.21256373; this version posted May 2, 2021. The copyright holder for this preprint (which was not certified by peer review) is the author/funder, who has granted medRxiv a license to display the preprint in perpetuity. It is made available under a CC-BY-NC-ND 4.0 International license.

Outcome Measure:

1. To identify undergraduate medical students' attitude towards research such as interest to participate in research work, familiarities with scientific methods, value of medical research and self-rated competency on study design and write scientific paper.

2. Students perceived barrier towards research such as lack of time, priorities and interest to do research, lack of familiarities with research methodologies and statistical analysis and insufficient guidance.

\section{Result:}

A total of 1279 student were responded to the questionnaire survey. Among them, $63.3 \%$ were female and $36.7 \%$ were male students. Response rate by academic year were $37 \%, 36.3 \%$, and $26.7 \%$ from $3^{\text {rd }}, 4^{\text {th }}$ and $5^{\text {th }}$ year students respectively.

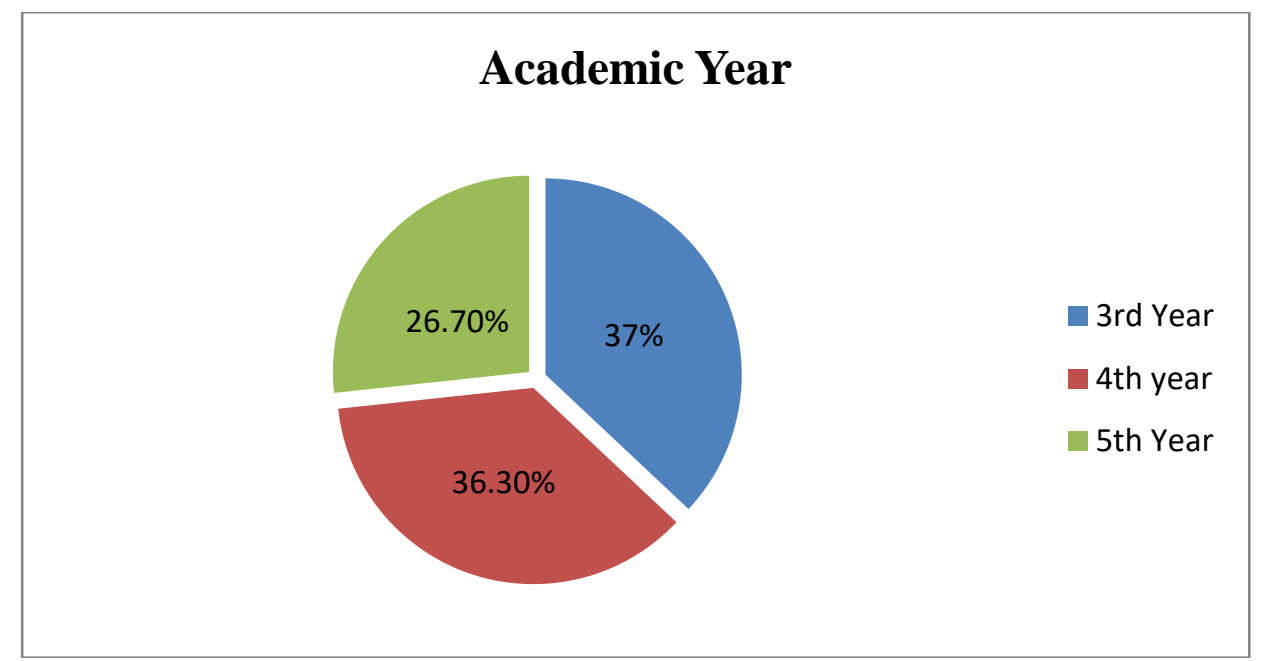

Fig 1: Distribution of undergraduate medical student according to academic year

Table I showed that $94 \%$ students responded that they are familiar with scientific method. $82.7 \%$ students mentioned that they can design and perform a research project and write scientific paper. More than half of the respondents (66.4\%) interested to participate in research. Almost all respondent (96.7\%) agreed that research is beneficial as it is helpful for critical thinking and policy implementation. $79.8 \%$ respondent opined that education on research methodology should be compulsory in the medical curriculum. 
medRxiv preprint doi: https://doi.org/10.1101/2021.04.30.21256373; this version posted May 2, 2021. The copyright holder for this preprint (which was not certified by peer review) is the author/funder, who has granted medRxiv a license to display the preprint in perpetuity.

It is made available under a CC-BY-NC-ND 4.0 International license .

Table 1: Undergraduate medical students' attitude towards research

\begin{tabular}{|l|l|l|l|}
\hline Attitude towards Research & \multicolumn{3}{|c|}{$\begin{array}{c}\text { Response(n=1279) } \\
\text { F=63.3\% } \mathrm{M}=36.7 \%\end{array}$} \\
\hline & $\begin{array}{l}\text { Totally } \\
\text { agree/agree }\end{array}$ & Disagree & $\begin{array}{l}\text { No } \\
\text { comments }\end{array}$ \\
\hline Familiarity with the scientific method & $94 \%$ & $2.1 \%$ & $3.8 \%$ \\
\hline $\begin{array}{l}\text { Design \& perform a research project and write } \\
\text { scientific paper }\end{array}$ & $82.7 \%$ & $7.8 \%$ & $9.6 \%$ \\
\hline Interested to participate in research work & $66.4 \%$ & $14.2 \%$ & $30.8 \%$ \\
\hline $\begin{array}{l}\text { Research is beneficial as it is helpful for critical } \\
\text { thinking and policy implementation }\end{array}$ & $96.7 \%$ & $0.4 \%$ & $2.7 \%$ \\
\hline $\begin{array}{l}\text { Education on Research Methodology should be } \\
\text { compulsory in the medical curriculum }\end{array}$ & $79.8 \%$ & $5.4 \%$ & $14.9 \%$ \\
\hline
\end{tabular}

Majority of the respondents $(89.1 \%)$ mentioned that lack of time and priorities to do research work because of compact academic tasks, lack of familiarities with research methodology (87.5\%) and statistical analysis $(85.2 \%)$ are the barrier of research. Insufficient guidance and lack of interest to do research also mentioned by $86.6 \%$ and $57.4 \%$ responded respectively. (Table II).

Table II: Undergraduate medical students' perceived barriers of research.

\begin{tabular}{|l|l|l|l|}
\hline Barriers of Research & \multicolumn{3}{|c|}{ Response(N=1279) } \\
\cline { 2 - 4 } & $\begin{array}{l}\text { Totally } \\
\text { agree/agree }\end{array}$ & Disagree & No comments \\
\hline $\begin{array}{l}\text { Lack of time and priorities to do } \\
\text { research because of compact academic } \\
\text { tasks }\end{array}$ & $89.1 \%$ & $2.3 \%$ & $8.4 \%$ \\
\hline $\begin{array}{l}\text { Lack of familiarity with Research } \\
\text { methodologies }\end{array}$ & $87.5 \%$ & $3.8 \%$ & $8.6 \%$ \\
\hline $\begin{array}{l}\text { Lack of familiarity with statistical } \\
\text { analysis }\end{array}$ & $85.2 \%$ & $3.8 \%$ & $10.9 \%$ \\
\hline $\begin{array}{l}\text { Inappropriate or insufficient guidance } \\
\text { for Research }\end{array}$ & $86.6 \%$ & $3.8 \%$ & $9.5 \%$ \\
\hline Lack of interest in Research & $57.4 \%$ & $25.3 \%$ & $17.3 \%$ \\
\hline
\end{tabular}

\section{Discussion:}

Early introduction to scientific research at the undergraduate level plays a noteworthy role in constructing an advanced medical education for students [21]. Undergraduate Research is the driving force behind a student's interest in what they are studying and thinking about. This is more than simply memorizing facts and figures for an exam and then forgetting about them until the exam is over. Conducting research necessitates sufficient awareness, a positive mindset, and the identification of research barriers [22]. The 
medRxiv preprint doi: https://doi.org/10.1101/2021.04.30.21256373; this version posted May 2, 2021. The copyright holder for this preprint (which was not certified by peer review) is the author/funder, who has granted medRxiv a license to display the preprint in perpetuity. It is made available under a CC-BY-NC-ND 4.0 International license .

aim of our survey was to determine undergraduate medical students' attitudes toward research and perceived barriers to conducting research.

Medical students with previous scientific research understanding usually have a more positive attitude regarding research [23]. According to our findings, the majority of students (94\%) are familiar with the scientific method. This result is satisfactory. Our findings contradict the findings of an earlier study by Osman T et al. (2020) in which half of the students reported a lack of familiarity with research [21]. Almost two-thirds of respondents self-rated their abilities to design and carry out research projects, as well as write scientific papers. In contrast to our findings, the ratter et al study (2018) found that undergraduate medical students rated their competencies as inadequate; especially in statistics and scientific writing [24]. Several studies have shown that students misjudge their competencies and believe they are under-trained [25]. In our survey, more than half of the respondents (66.4\%) expressed an interest in participating in research. Several studies have found similar results, with students expressing a positive attitude toward research [24, 26, 27]. Students already have a high degree of stress as a result of the overburdened medical curriculum, and they do not have sufficient room to do research or spend time on research [28]. Therefore it is essential that design and content of the medical curriculum should reallocate time that students have enough time on research.

The most significant characteristics of undergraduate research are critical thinking and problem-solving abilities. Medical students should be encouraged to conduct research and improve their analytic skills, which are in high demand right now [29]. According to our findings, undergraduate students believe that research is beneficial and useful for critical analysis and policy implementation. Similar findings were found in the Houlden et al. (2016) study, where students appreciated the role of research in improving critical thinking when carrying out research projects during their study period [30]. Tomorrows Doctors, the Scottish Deans Medical Education Group, and by the Manual for Good Medical Practice USA all strongly recommend encouraging research-specific skills as well as the development of critical thinking, time management, communication skills, and teamwork among undergraduate medical students. [29, 3133]. In the current survey, more than two-thirds (79.8\%) of students thought that research methods should be taught in the undergraduate curriculum. A study also reported that, $60 \%$ of medical students agreed to include research methodology in their medical curriculum [34]. The rationale for including research methods in medical curricula may be to facilitate research experience during medical studies. This will foster a positive attitude toward research and critical appraisal of the medical literature, as well as encourage interest in medical research as an academic career [12]. 
medRxiv preprint doi: https://doi.org/10.1101/2021.04.30.21256373; this version posted May 2, 2021. The copyright holder for this preprint (which was not certified by peer review) is the author/funder, who has granted medRxiv a license to display the preprint in perpetuity. It is made available under a CC-BY-NC-ND 4.0 International license .

Our study attempted to investigate the research barriers mentioned by Bangladeshi medical students. The majority of students cited that lack of time and priorities for conducting research as a result of their compact academic workload. The lack of familiarity with scientific methods and statistical analysis is cited as barriers to research by $87.7 \%$ of students. This might be due to insufficient emphasis given in research methodology and statistical analysis during medical study. To assist undergraduate students, medical college can host a seminar on scientific research to educate them and clear up any misconceptions about the nature and value of scientific research [26]. Consistent with our findings Pallamparthy S et al.(2019) study found that students stated lack of knowledge (53\%), lack of interest (54 $\%)$, financial grants (62\%), and lack of time as obstacles to research (59\%) [34]. Another study by El Achi D et al. (2020) found that 56\% student believe research is not a waste of time and does not interfere with studies, even though some medical students believe their courses are more important than allocating time for medical research [24]. Similar barriers to research were also explored in studies from various countries $[15,16,18]$.

In the current study, $86.6 \%$ stated that insufficient guidance is an important barrier of research. This might be due to medical faculty or principal investigators pay less emphasis on allocating undergraduate students [26]. According to the findings of the Funston et al.(2019) study, students face a lack of supervision and direction while conducting research [35]. In fact, according to a study conducted by Ahn J et al. (2007) pointed out that undergraduate students are concerned about finding the right balance between clinical and academic education [36]. Appropriate feedback by teacher can facilitate students to have a positive research mindset. Medical educators should place a greater focus on the challenges identified by students, such as mentoring and guidance, in order to improve undergraduate medical students' research experiences [26].

\section{Conclusion}

Undergraduate medical students of Bangladesh were enthusiastic about conducting medical research. The majority of medical students of Bangladesh believe that research methods should be included in the undergraduate curriculum. Due to condensed academic activities; there is a lack of time and goals for research work, as well as a lack of familiarity with research methods, statistical analysis, and poor guidance. Our findings may be used to improve undergraduate student research in medical education and as a recommendation for overcoming obstacles.

\section{References:}

1. $\quad$ Sackett DL, Rosenberg WM, Gray JA, Haynes RB, Richardson WS. Evidence based medicine: what it is and what it isn't. BMJ. 1996;312(7023):71-72 


\begin{tabular}{|c|c|}
\hline 2 & $\begin{array}{l}\text { Vujaklija A, Hren D, Sambunjak D, Vodopivec I, Ivanis A, Marusić A, et al. Can teaching research } \\
\text { methodology influence students' attitude toward science? Cohort study and nonrandomized trial in a } \\
\text { single medical school. J Investig Med. 2010;58:282-6. }\end{array}$ \\
\hline 3. & $\begin{array}{l}\text { Halstead J. Council on Undergraduate Research: A resource (and a community) } \\
\text { for science educators. J Chem Educ. 1997;74(2):148-9. }\end{array}$ \\
\hline 4 & $\begin{array}{l}\text { Seymour E, Hunter A, Laursen SL, Deantoni T. Establishing the benefits of } \\
\text { research experiences for undergraduates in the sciences: First findings from } \\
\text { a three-year study. Sci Educ. 2004;88:493-534. }\end{array}$ \\
\hline 5. & $\begin{array}{l}\text { Ommering BWC, Wijnen-Meijer M, Dolmans DHJM, Dekker FW, van Blankenstein FM. } \\
\text { Promoting positive perceptions of and motivation for research among undergraduate medical } \\
\text { students to stimulate future research involvement: a grounded theory study. BMC Med Educ. } \\
\text { 2020;20(1):204. }\end{array}$ \\
\hline 6 & $\begin{array}{l}\text { The Council on Undergraduate Research - Learning Through Research | Membership, Publications, } \\
\text { Conferences \& Events, Projects \& Services, Governance, Advocacy and Resources | Council on } \\
\text { Undergraduate Research [Internet]. Cur.org. 2021 [cited } 28 \text { April 2021]. Available from: } \\
\text { https://www.cur.org/ }\end{array}$ \\
\hline 7. & (GMC) G.M.C. 2018. Outcomes for Graduates 2018. \\
\hline 8. & $\begin{array}{l}\text { Murdoch-Eaton D., Ellershaw J., Garden A., Newble D., Perry M., Robinson L. Student-selected } \\
\text { components in the undergraduate medical curriculum: a multi-institutional consensus on purpose. } \\
\text { Med. Teach. 2004;26:33-38. }\end{array}$ \\
\hline 9. & $\begin{array}{l}\text { Dagher MM, Atieh JA, Soubra MK, Khoury SJ, Tamim H, Kaafarani BR. Medical research } \\
\text { volunteer program (MRVP): innovative program promoting undergraduate research in the medical } \\
\text { field. BMC Med Educ. 2016;16:160. }\end{array}$ \\
\hline 10. & Biswas RS, Biswas CR. Success and failure in medical research. J Sci Soc 2016;43:106-7. \\
\hline 11 & Rash EM. A service learning research methods course. J Nurs Educ. 2005;44:477-478. \\
\hline 12 & $\begin{array}{l}\text { Aslam F, Shakir M, Qayyum MA. Why medical students are crucial to the future of research in } \\
\text { South Asia?? PLoS Med. 2005;2:e322. } \\
\text { http://journals.plos.org/plosmedicine/article?id=10.1371/journal.pmed.0020322. }\end{array}$ \\
\hline 13 & $\begin{array}{l}\text { BIMSSCONN. 2021. Bangladesh Intentional Medical Students' scientific Congress. [online] } \\
\text { Available at: <https://www.facebook.com/BIMSSCON/> [Accessed } 23 \text { April 2021]. }\end{array}$ \\
\hline 14 & $\begin{array}{llll}\text { Ifmsabd.org. 2021. IFMSA Bangladesh - Empowering } & \text { Medicos. [online] Available at: } \\
\text { <http://ifmsabd.org/> [Accessed 23 April 2021]. } & & & \\
\end{array}$ \\
\hline 15. & $\begin{array}{l}\text { Kyaw Soe HH, Than NN,Lwin H, Nu Htay MN, Phyu KL, Abas AL. Knowledge, attitudes, and } \\
\text { barriers toward research: The perspectives of undergraduate medical and dental students. J Edu } \\
\text { Health Promot 2018;7:23. }\end{array}$ \\
\hline 16 & $\begin{array}{l}\text { Athanasakis E. Nurses' research behaviour and barriers to research utilization into clinical nursing } \\
\text { practice: A close look. Int J Caring Sci 2013; 6:16-28. }\end{array}$ \\
\hline 17 & $\begin{array}{l}\text { Goyal RC. Research Methodology for Health Professionals. 1st ed. New Delhi: Jaypee Brothers } \\
\text { Medical Publishers; } 2013 .\end{array}$ \\
\hline 18 & $\begin{array}{l}\text { Amin T, Kaliyadan F, Abdulatheem EA, Majed M, Khanjaf H, Mirza M. Knowledge, attitudes and } \\
\text { barriers related to participation of medical students in research in three Arab Universities. Educ } \\
\text { Med J. 2012;4:e47-55. }\end{array}$ \\
\hline 19 & $\begin{array}{l}\text { Grobman, L. 2010. "Researching the Conflicts: Undergraduate Research and the Introductory } \\
\text { Literature Curriculum." Teaching English in the Two Year College } 37 \text { (4): 372-383. }\end{array}$ \\
\hline 20 & $\begin{array}{l}\text { Khan H, Taqui AM, Khawaja MR, Fatmi Z. Problem-based versus conventional curricula: influence } \\
\text { on knowledge and attitudes of medical students towards health research. PLoS One. }\end{array}$ \\
\hline
\end{tabular}




\begin{tabular}{|c|c|}
\hline & 2007;2(7):e632. \\
\hline 21. & $\begin{array}{l}\text { Osman T. Medical students' perceptions towards research at a Sudanese university. BMC Med } \\
\text { Educ. 2016;16 }\end{array}$ \\
\hline 22. & $\begin{array}{l}\text { Siamian H, Mahmoudi R, Habibi F, Latifi M, Zare-Gavgani V. Students' attitudes towards research } \\
\text { at Mazandaran University of medical sciences in 2015. Mater Sociomed. 2016;28:468-72. }\end{array}$ \\
\hline 23. & $\begin{array}{l}\text { Siemens DR, Punnen S, Wong J, Kanji N. A survey on the attitudes towards research in medical } \\
\text { school. BMC Med Educ. 2010;10:4. }\end{array}$ \\
\hline 24. & $\begin{array}{l}\text { Ratte A. The importance of scientific competencies in German medical curricula - the student } \\
\text { perspective. BMC. 2018;18:146 }\end{array}$ \\
\hline 25. & $\begin{array}{l}\text { Caspi O, McKnight P, Kruse L, Cunningham V, Figueredo AJ, Sechrest L. Evidence-based } \\
\text { medicine: discrepancy between perceived competence and actual performance among graduating } \\
\text { medical students. Med Teach. } 2006 ; 28: 318-25 \text {. }\end{array}$ \\
\hline 26. & $\begin{array}{l}\text { El Achi D, Al Hakim L, Makki M, Mokaddem M, Khalil PA, Kaafarani BR, Tamim H. Perception, } \\
\text { attitude, practice and barriers towards medical research among undergraduate students. BMC Med } \\
\text { Educ. 2020;20(1):195. }\end{array}$ \\
\hline 27. & $\begin{array}{l}\text { Hren D, Lukić IK, Marusić A, Vodopivec I, Vujaklija A, Hrabak M, et al. Teaching research } \\
\text { methodology in medical schools: students' attitudes towards and knowledge about science. Med } \\
\text { Educ. 2004;38:81-6. }\end{array}$ \\
\hline 28. & $\begin{array}{l}\text { Prinz P, Hertrich K, Hirschfelder U, de Zwaan M. Burnout, depression and depersonalisation- } \\
\text { psychological factors and coping strategies in dental and medical students. GMS Z Med Ausbild. } \\
\text { 2012;29:1-14. }\end{array}$ \\
\hline 29 & $\begin{array}{l}\text { Detsky MED, Detsky AS. Encouraging medical students to do research and write papers. CMAJ. } \\
\text { 2007;176:1719_21 }\end{array}$ \\
\hline 30. & $\begin{array}{l}\text { Houlden RL, Raja JB, Collier CP, Clark AF, Waugh JM. Medical students' perceptions of an } \\
\text { undergraduate research elective. Med Teach. 2009;26:659-61. }\end{array}$ \\
\hline 31. & $\begin{array}{l}\text { General Medical Council UK. Tomorrows Doctors, outcomes and standards for undergraduate } \\
\text { medical education. September } 2009 \text {. }\end{array}$ \\
\hline 32. & $\begin{array}{l}\text { Scottish Deans Medical Education Group. The Scottish Doctor: learning outcomes for the medical } \\
\text { undergraduate in Scotland: a foundation for competent and reflective practitioners. 3rd } \\
\text { ed.Edinburgh, UK: Scottish Deans Medical Education Group;2009. }\end{array}$ \\
\hline 33. & $\begin{array}{l}\text { National Alliance for Physician Competence. Good medical practice _ USA: the National Alliance. } \\
\text { Version 1.0; } 2007 .\end{array}$ \\
\hline 34. & $\begin{array}{l}\text { Pallamparthy S, Basavareddy A. Knowledge, attitude, practice, and barriers toward research among } \\
\text { medical students: A cross-sectional questionnaire-based survey. Perspect Clin Res. 2019;10(2):73- } \\
78 \text {. }\end{array}$ \\
\hline 35. & $\begin{array}{l}\text { Funston G, Piper RJ, Connell C, Foden P, Young AMH, O'Neill P. Medical student perceptions of } \\
\text { research and research-orientated careers: an international questionnaire study. Med Teach. } \\
\text { 2016;38:1041-8 }\end{array}$ \\
\hline 36. & $\begin{array}{l}\text { Ahn J, Watt CD, Man LX, Greeley SW, Shea JA. Educating future leaders of medical research: } \\
\text { analysis of student opinions and goals from the MD-PhD SAGE (students' attitudes, goals, and } \\
\text { education) survey. Acad Med. 2007;82: 633-45. }\end{array}$ \\
\hline
\end{tabular}

